\title{
New records of thrips (Thysanoptera: Phlaeothripidae) from
} Karnataka, India

\author{
Kaomud Tyagi and Vikas Kumar* \\ Centre for DNA Taxonomy (CDT), Molecular Systematics Division (MSD), Zoological Survey of India, M-Block, New Alipore, Kolkata, 700053, West \\ Bengal, India, \\ * Corresponding author. E-mail: vikaszsi77@gmail.com
}

\begin{abstract}
Four species, two each in the subfamily Idolothripinae and Phlaeothripinae are being reported for the first time from Karnataka State, India. Diagnostic features, distribution and data on material studied for these species are given.
\end{abstract}

The family Phlaeothripidae is the only family under the suborder Tubulifera and the largest in Thysanoptera. It comprises two subfamilies, Idolothripinae and Phlaeothripinae recognisable on the basis of width of maxillary stylets. This family currently includes about 3500 species worldwide (Mound and Minaei, 2007), and about 10\% of these species are known from India (Tyagi and Kumar 2011). So far 64 species in 35 genera have been reported from Karnataka (Ananthakrishnan and Sen 1980; Tyagi and Kumar 2011, 2012; Tyagi 2012). In a recent survey, four species of this family Ethirothrips obscurus (Schmutz) and Loyolaia indica Ananthakrishnan in the subfamily Idolothripinae and Liophloeothrips succinctus Ananthakrishnan and Jagadish and Lygothrips jambuvasi (Ramakrishna) in the subfamily Phlaeothripinae were discovered and are reported here for the first time from Karnataka.

Specimens were collected by the beating method wereand preserved in collecting fluid ( 9 parts $10 \%$ alcohol +1 part glacial acetic acid +1 ml Triton X-100 in $1000 \mathrm{ml}$ of the mixture) and mounted in Canada balsam (Bhatti 1999). Photographs were taken through a Leica stereo zoom Microscope (Leica M 205A) using Leica software application suite (LAS V3.8). Species were identified with the help of the keys in Ananthakrishnan and Sen (1980) and Tyagi and Kumar (2011).

The classification adopted in the article is that of Mound, Heming and Palmer (1980). Voucher specimens are deposited in National Zoological Collections of Zoological Survey of India, Kolkata, West Bengal, Ministry of Environment and Forests, India.

\section{Family Phlaeothripidae}

\section{Subfamily Idolothripinae}

Ethirothrips obscurus (Schmutz 1913) [1B]

Dichaetothrips indicus Ananthakrishanan 1961, Zool. Anz., 167(7-8): 269-270.

Diagnosis: Both sexes macropterous. Body dark brown including legs except tibiae and all tarsi yellow to brownish yellow. Antennal segments I-II and VII-VIII brown; III and IV yellow to brownish yellow. Head longer than broad.
All dorsal prothoracic setae well-developed. Antennal segment III with 2 and IV with 4 sense cones. Fore tarsus with tooth. Fore wings transparent with 11-15 duplicated cilia. Tube longer than head.

Material studied: $1 q$, INDIA: Karnataka: Bangalore, IIHR (Indian Institute of Horticultural Research), 24.iii.2012; 3 ㅇ, 9.v.2012, on general vegetation; 1 ,, $1 \hat{\jmath}$, GKVK (Gandhi Krishi Vigyan Kendra), 1.v.2012, Pongamia pinnata; 1 , , Judicial Layout, 21.ii.2012, unidentified plant; 1 ㅇ, $1 \hat{\jmath}$, Machanahalli, 12.viii.2012, Arecanut; $1+, 1 \hat{\jmath}$, Kanakpura, Harohalli, 3.viii.2012; dry twigs of coconut; 1 , Hompalgata, 29.xii.2012, Cassia occidentalis, Sureshkumar (Reg. No. 5103/ H17 to 5114/ H17)

Distribution: India: Andhra Pradesh, Bihar, Karnataka (new record), Tamil Nadu, Uttarakhand.

\section{Loyolaia indica Ananthakrishnan 1964 [1A]}

Loyolaia indica Ananthakrishnan 1964, Ent. Tids., 85(1-2): 107-108.

Diagnosis: Both sexes apterous. Body bicoloured; head, thorax, all femora and tibiae yellow; abdomen and all tarsi blackish brown. Antennal segment I-IV yellow, V-VIII blackish brown. Head as long as broad. Mouthcone broadly rounded. Postocular setae long and pointed. All dorsal prothoracic setae well developed. Fore tarsus with small tooth. Basantra present. Antennal segment III with one sense cone and IV with 4 sense cones. Tube as long as head.

Material studied: 3 , INDIA: Karnataka: Vijayapura, Gudavanahalli, 13.vii.2012, grass, Sureshkumar (Reg. No.5115/H17 to 5117/ H17)

Distribution: India: Karnataka (new record), Tamil Nadu.

\section{Family Phlaeothripidae}

\section{Subfamily Phaleothripinae}

Liophloeothrips succinctus Ananthakrishnan and Jagadish [1D]

Liophlaeothrips succinctus Ananthakrishnan and Jagadish 1969, Marcellia, 44.

Diagnosis: Both sexes macropterous. Body dark 
brown except middle and anterior margin of fore tibiae and tarsi yellow. Antennal segments I-II and VIII brown, III-VII yellow. Wings transparent. Maxillary stylets not close together, wide apart; pronotal anteroangulars longer than anteromarginals; postocular setae shorter than eyes; fore tarsus with small tooth; metanotum with reticulate sculpture.

Material studied: $5 \circ, 1 \hat{\jmath}$, INDIA: Karnataka: Magadi, 25.iv.2012, leaf galls of wild plant, Sureshkumar (Reg. No. 5118/ H17 to 5123/ H17)

Distribution: India: Karnataka (new record), Kerala.

\section{Lygothrips jambuvasi (Ramakrishna 1928) [1C]}

Eothrips jambuvasi Ramakrishna 1928, Mem. Dept. Agr. Ind. Ent. Ser. 10(7): 300-301.

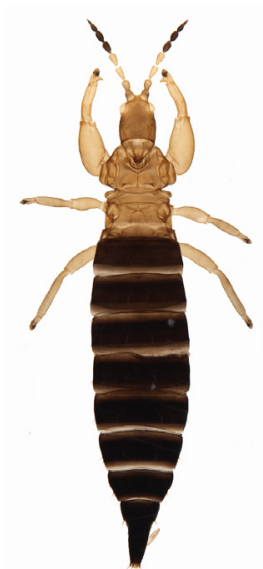

A
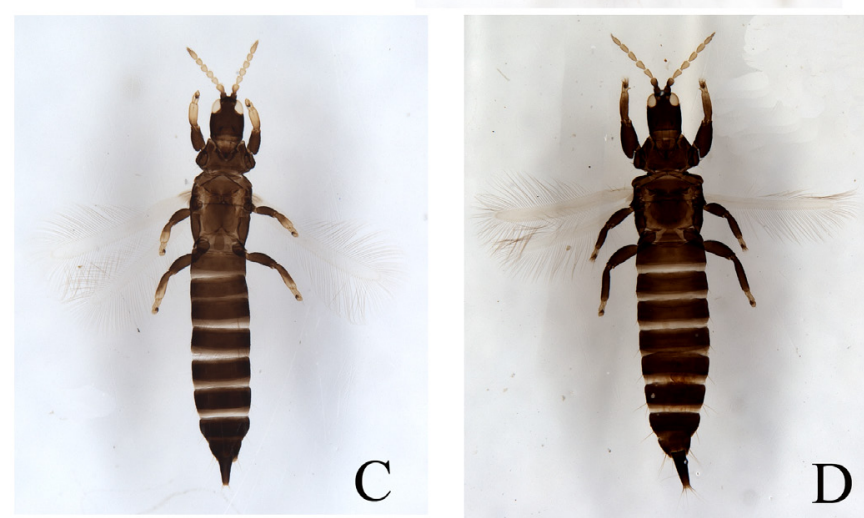

FIGURE 1 (A-D). A. Loyolaia indica, male; B. Ethirothrips obscurus, female; C. Lygothrips jambuvasi, female; D. Liophloeothrips succinctus female.
Diagnosis: Body brown. Head as broad as long. Antennal segment VII longer than III, IV or V. Cheeks parallel-sided. Mouth cone broadly rounded. Prothoracic anteroangular, anteromarginal and midlateral setae poorly developed. Fore tarsus without tooth in both sexes.

Material examined: 3 , INDIA: Karnataka: Kunigal, 18.x.2012, galls of Eugenia sp., Sureshkumar (Reg. No. 5124/ H17 to 5126/ H17).

Distribution: India: Andhra Pradesh, Karnataka (new record), Madhya Pradesh, Tamil Nadu.

ACKNOWLEDGMENTS: The authors are grateful to Dr. K. Venkataraman for her encouragement and moral support and providing necessary facilities. This study is financially supported by the SERB, Department of Science \& Technology through DST Young Scientist Project entitled "Molecular Systematics and Phylogeny of Economically Important Thrips (Thysanoptera: Insecta) of India" (SR/FT/LS-24/2012), to the first author.

\section{Literature Cited}

Ananthakrishnan, T.N. 1961. Studies on some Indian Thysanoptera VI. Zoologischer Anzieger 167: 259-271.

Ananthakrishnan, T.N. 1964. Thysanopterologica Indica- I. Entomologisk Tidskrift 85(1-2): 99-120.

Ananthakrishnan, T.N. and A. Jagadish 1969. Studies on Indian Gall Thrips (Thysanoptera). Marcellia 36(1-2): 7-103.

Ananthakrishnan, T.N. and A. Jagadish, 1970. The Species of Diceratothrips Bagnall and Allied Genera from India. (Thysanoptera: Megathripinae: Insecta). Oriental Insects 4(3): 266-268.

Ananthakrishnan, T.N. and S.Sen, 1980. Taxonomy of Indian ThysaopteraVolume 1. Handbook Series. Kolkata: Zoological Survey of India. 234 p.

Bhatti, J.S. 1999. Notes on Thysanoptera. Thrips 1: 6-9.

Mound L.A., B.S. Heming and J.M. Palmer. 1980. Phylogenetic relationships between the families of recent Thysanoptera. Zoological Journal of the Linnean Society of London 69: 111-141.

Mound, L.A. and K. Minaei 2007. Australian thrips of the Haplothrips lineage (Insecta: Thysanoptera). Journal of Natural History 41(4548): 2919-2978.

Ramakrishna Ayyar, T. V. 1928. A contribution to our knowledge of the Thysanoptera of India. Memoirs of the Department of Agriculture in India, Entomological Series 10(7): 217-316.

Tyagi,K.2012. New records of Tubulifera (Thysanoptera: Phlaeothripidae) from the state of Karnataka, India. Journal of Threatened Taxa 4(5): 2596-2602.

Tyagi, K. and V. Kumar, 2011. The Indian species of Liophloeothrips Priesner (Thysanoptera, Phlaeothripidae) with one new species. Zootaxa 2803: 21-31.

Tyagi, K. and V. Kumar, 2012. A new species of Psephenothrips Reyes (Thysanoptera: Phlaeothripidae) from India. Oriental Insects 46(34): 281-287.

RECEIVED: March 2013

ACCEPTED: August 2013

Published online: October 2013

EDITORIAL RESPONSIBILITY: Matthew Smart 